\title{
The Effects of an Absorbable Hemostat Produced From Oxidized Regenerated Cellulose on Adhesion Formation in a Rat Model
}

\section{Oksitlenmiş Rejenere Selülozdan Üretilen Absorbe Edilebilir Bir Hemostatın Rat Modelinde Adezyon Oluşumu Üzerine Etkisi}

\author{
(10) Adem Yavuz1', (1) Gökalp Öner², (1) Mustafa Taş33, (1) Selim Çınaroğlu4 \\ ${ }^{1}$ Niğde Ömer Halisdemir University Faculty of Medicine, Department of Obstetrics and Gynecology, Niğde, Turkey \\ ${ }^{2}$ Acıbadem Kayseri Hospital, Clinic of Obstetrics and Gynecology, Kayseri, Turkey \\ ${ }^{3}$ Acıbadem Mehmet Ali Aydınlar University, Department of Obstetrics and Gynecology, İstanbul, Turkey \\ ${ }^{4}$ Niğde Ömer Halisdemir University Faculty of Medicine, Department of Anatomy, Niğde, Turkey
}

\begin{abstract}
Objective: This study aimed to analyze the effect of an absorbable hemostat produced from oxidized regenerated cellulose (ORC) on pelvic adhesion formation in a rat model using an adhesion scoring system and immunohistochemical staining.

Methods: This randomized, controlled experimental study included 20 female Wistar-Albino rats that were equally divided into the following groups: control and absorbable hemostat groups. The uterine horns of all the rats were exposed by laparotomy and using $10 \mathrm{~W}$ bipolar cautery. Five standard lesions were applied to the antimesenteric areas of each uterine horn. The experimental group received an absorbable hemostat to the traumatized uterine surfaces, whereas the control group did not. After a 28-day follow-up period, a relaparotomy was performed, and adhesions were evaluated based on an adhesion scoring system, and histological sections from areas with adhesion were obtained for immunohistochemical staining. Immunohistochemical staining included analysis of Ki-67 (proliferation index), CD-31 (neovascularization index), and Masson Trichrome [(MTC) fibrosis and collagen formation index]. Additionally, acute and chronic inflammation indices were determined via polymorphonuclear leukocytes (PMNL) and mononuclear leukocytes (MNL), respectively.

Results: The intensity and scope of adhesion and overall adhesion ratings were substantially higher in the absorbable hemostat group than the control group ( $2.8 \pm 0.85$ vs. $2.2 \pm 0.53,0.92 \pm 0.26$ vs. $0.61 \pm 0.25$, and $3.72 \pm 0.96$ vs. $2.81 \pm 0.75$, respectively). Staining results for Ki- $67, C D-31$, MTC, PMNL, and MNL were also significantly higher in the absorbable hemostat group than in the control group ( $p<0.05$ for all).

Conclusion: The obtained results suggest that the use of ORC-based absorbable hemostats in pelvic surgery may increase adhesion formation on peritoneal surfaces by increasing inflammation, vascularity, and collagen formation.
\end{abstract}

Keywords: Pelvic, adhesion, surgical hemostasis, rats

\section{öz}

Amaç: Bu çalışmanın amacı, okside rejenere sellülozdan (ORC) üretilen absorbe edilebilir bir hemostatın rat modelinde pelvik adezyon oluşumu üzerindeki etkisini adezyon skorlama sistemi ve immünohistokimyasal boyama kullanarak değerlendirmektir.

Gereç ve Yöntem: Çift kör, randomize, kontrollü bir deneysel çalışma tasarlandı. Yirmi dişi Wistar-Albino rat eşit olarak kontrol ve absorbe edilebilir hemostat gruplarına ayrıldı. Tüm ratların uterin hornları laparotomi ile ortaya çıkarıldı ve her uterus hornunun antimezenterik yüzeyine 10 W bipolar koter kullanılarak beş standart lezyon uygulandı. Deney grubunda travmatize olmuş uterin yüzeylere absorbe edilebilir hemostat uygulanırken, kontrol grubuna herhangi bir müdahale yapılmadı. Yirmi sekiz günlük bir takip süresinin ardından tekrar laparotomi yapıldı ve adezyon skorlama sistemine göre adezyonlar değerlendirildi ve immünohistokimyasal boyama için adezyonlu alanlardan histolojik kesitler alındı. İmmünohistokimyasal boyama, Ki-67 (proliferasyon indeksi), CD-31 (neovaskülarizasyon indeksi) ve Masson Trikrom [(MTC), fibrozis ve kollajen oluşum indeksi] analizini içeriyordu. Ek olarak, sırasıyla polimorfonükleer lökositler (PMNL) ve mononükleer lökositler (MNL) aracılığıyla akut ve kronik enflamasyon indeksleri belirlendi.

Address for Correspondence: Adem Yavuz, Niğde Ömer Halisdemir University Faculty of Medicine, Department of Obstetrics and Gynecology, Niğde, Turkey

Phone: +90 5378223425 E-mail: ademyavuz@ohu.edu.tr ORCID ID: orcid.org/0000-0003-4191-4004

Cite as: Yavuz A, Öner G, Taş M, Çınaroğlu S. The Effects of an Absorbable Hemostat Produced From Oxidized Regenerated Cellulose on Adhesion Formation in a Rat Model. Med J Bakırköy 2021;17:142-148 
Bulgular: Adezyon şiddeti ve yaygınlığı ile toplam adezyon skorları, kontrollere kıyasla absorbe edilebilir hemostat grubunda anlamlı düzeyde

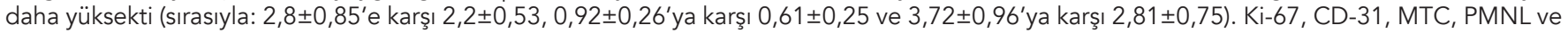
MNL için boyama sonuçları da emilebilir hemostat grubunda kontrol grubuna göre anlamlı düzeyde daha yüksekti (tümü için $p<0,05)$.

Sonuç: Bulgularımız, pelvik cerrahide ORC bazlı absorbe edilebilir hemostat kullanımının enflamasyon, vaskülarite ve kollajen oluşumunu artırarak peritoneal yüzeylerde adezyon oluşumunu artırabileceğini düşündürmektedir.

Anahtar Kelimeler: Pelvik, adezyon, cerrahi hemostaz, sıçanlar

\section{INTRODUCTION}

Generally, the most serious complication following abdominal and pelvic surgery is adhesion formation. This postoperative problem has been linked with numerous morbidities, including small bowel obstruction, increased risk for inadvertent bowel injury in later surgeries, increased operation time, chronic abdominal pain, decreased likelihood of pregnancy, increased fertility treatments, and intraoperative complications (1). Although the pathogenesis of adhesion formation is still not well known, it is well recognized that an imbalance between fibrin deposition and fibrinolysis is the keystone of adhesion formation. Several elements such as tissue hypoxia and elevated inflammation, however, lead to a cytokine-rich setting that blocks the deposited fibrin lysis. As a result, fibrin clots remain organized and are usually degraded within a few days, and the infiltration of fibroblasts and other cells allows the clot to be reorganized into healthy connective tissues (2).

Topical hemostatic agents produced from oxidized regenerated cellulose (ORC), when applied dry, have a greater hemostatic effect and can be easily and firmly attached to bleeding tissues until hemostasis is achieved (3). ORC facilitates hemostasis by activating coagulation on the collagen surface, and since it has a lower $\mathrm{pH}$, it plays a role as a caustic hemostatic agent. Thus, it is favored instead of gelatin foam in contaminated locations $(4,5)$. Despite these well-established advantages, low pH can cause tissue infection and delay recovery. This is particularly important since some materials may remain within the tissues for a long time (up to several months or years), although the majority is absorbed within 7 to 14 days $(4,6)$. In line with the advantages listed before, studies have shown that the status of topical hemostatic agents in minimally invasive gynecologic operations has not been specifically identified, but topical hemostatic agents that originated from ORC can efficaciously achieve hemostasis, decrease blood loss, minimize operative times, and reduce transfusion needs (7). Numerous animal studies with different methodologies have been performed to elucidate the effects of ORC-based absorbable hemostats on adhesion formation in rat models, but the results have been inconsistent (8-12).
This experimental work was prepared to elucidate the effects of an ORC-based absorbable hemostat on adhesion formation in uterine horn lesions of rats, as measured by a clinical adhesion scoring system and immunohistochemical staining for Ki-67, CD-31, masson trichrome (MTC), polymorphonuclear leukocytes (PMNL), and mononuclear leukocytes (MNL).

\section{METHODS}

In our study, experimental animals were used for research in Niğde Ömer Halisdemir University Laboratories according to the approval of the Local Animal Studies Ethics Committee (date: July 20, 2020, approval number: 2020/09).

A total of 20 female Wistar-Albino rats, aged 20-24 weeks and weighing 180-210 g, were kept in standardbedding cages with controlled environment temperatures $\left(22^{\circ} \mathrm{C} \pm 2^{\circ} \mathrm{C}\right)$. Day/night cycles were mimicked with a $12 / 12 \mathrm{~h}$ light/dark period, and adequate food and water were provided ad libitum. The animals were divided into two groups as follows: control (sham operation) and intervention groups (absorbable hemostat recipients). They were evaluated twice a week for weight changes and behavioral characteristics by a research team member who did not partake in later procedures or measurements. The veterinary staff of the facility performed routine checks on the animals every day. Any notable changes were reported to the principal researcher and dealt with according to a unanimous decision from the researchers.

Procedures for both groups were carried out in the same fashion. Anesthesia was performed using $50 \mathrm{mg} / \mathrm{kg}$ ketamine hydrochloride (Ketalar ${ }^{\circledR}$, flakon, Eczacibasi, İstanbul, Turkey) and $7 \mathrm{mg} / \mathrm{kg}$ xylazine hydrochloride (Rompun ${ }^{\circledR}$, Bayer, Germany) via intraperitoneal administration. The abdominal skin of the animals was sanitized with a $10 \%$ povidone-iodine solution. The uterine horns were exposed by laparotomy access via a $3 \mathrm{~cm}$ midline incision, and five standard lesions were applied in the antimesenteric surfaces of each uterine horn using a $10 \mathrm{~W}$ bipolar cautery (applied for $1 \mathrm{~s}$ ), as previously described (13). The lesion-forming procedure was performed meticulously to avoid damaging tissues in other sites. The traumatized uterine surfaces of the absorbable hemostat group were covered with a 1 
$\mathrm{cm}^{2}$-sized ORC-based absorbable hemostat (Surgicel $\AA_{\text {, }}$ Ethicon SARL, Neuchatel, Switzerland), whereas there was no application of medication to the control group. The incision was covered in two strata with a 4-0 Prolene suture (Ethicon, Inc., Somerville, NJ, USA) for the peritoneum and 3-0 Prolene suture for the dermis. The same researcher (S.C.) conducted all laparotomy processes and was given closed envelopes containing the description of the final intervention to be performed after completing all other steps of the laparotomy. No antibiotic prophylaxis was given during the research. A total of two rats died within 24 $\mathrm{h}$ after the procedure because of anesthesia complications (one from each group). Two days after the procedure, the abdominal wall scars of each rat were inspected for signs of infection.

After a 28-day follow-up period, all rats $(n=18)$ underwent relaparotomy with the same anesthesia procedures applied in the first laparotomy. The 28-day duration was determined based on the absorption characteristics of ORC (beginning within $24 \mathrm{~h}$ and usually dissolving completely within 2-6 weeks) $(6,14,15)$. Adhesion scoring was performed, and biopsy samples were taken from adhesion sites for histological examination. Adhesion scores were classified according to Linsky et al. (16) clinical adhesion scoring system and performed by a different researcher (A.Y.) who was blinded to the rat groups. The degree of adhesion was measured as follows: $0=$ no adhesion, $1=25 \%$ of the surface covered, $2=50 \%$ of the surface covered, and $3=$ fully covered. Adhesion intensity was calculated as follows: $0=$ no resistance to separation, $0.5=$ some resistance, and $1=$ need for sharp dissection. The overall score was obtained by summarizing these two different scores.

The biopsy samples taken were fixed with formalin, embedded in paraffin blocks, divided into about $4 \mu \mathrm{m}$ thickness, and, after immunohistochemical coloring, examined with a Zeiss Scope A1 microscope (Germany) by a pathologist (Y.P.) irrelevant to the study. While evaluating the results, the pathologist assessed frequently addressed features such as collagen formation, fibrosis, inflammation, neovascularization, and cellular proliferation in histological evaluations. Ki-67 staining was used (NCL-L-Ki67-MM1; Leica, New Castle, UK) for the proliferation index, CD-31 staining (NCL-CD31-1A10; Leica) for the neovascularization index, and MTC staining (Bio Optica, Milan, Italy) for the fibrosis and collagen formation index. The Ki-67 marker is a proliferation marker that has gained unanimous acceptance for its role in quantifying the expression of mitotic cells, and it has been demonstrated to be associated with adhesion formation $(17,18)$. CD-31 is an angiogenesis marker found to have increased expression during the development of new blood vessels (neovascularization). It has been correlated positively with adhesion formation in previous studies $(19,20)$. Collagen formation can be measured by MTC, a marker that is important in fibrosis and may be related to the degree of fibrosis (19). In addition, PMNL was evaluated for the acute inflammation index after staining with hematoxylin-eosin and MNL for the chronic inflammation index. To assess the immunohistochemical staining ratings, an updated scoring method was used as follows: $0=$ no expression, $1=$ mild, $2=$ moderate, and $3=$ intense staining (8).

\section{Statistical Analyses}

SPSS version 15.0 (SPSS Inc., Chicago, IL, USA) was utilized to evaluate the statistical analyses in the study. The comparison of nonnormally distributed quantitative and normally distributed variables were assessed using the Mann-Whitney $U$ and Student's t-tests, respectively. Statistical significance was defined as $p<0.05$. All values were described as mean \pm standard deviation, regardless of the actual statistical method used for comparisons (parametric or nonparametric). The Sigma-Stat 3.5 software was used for power analysis. These values are listed under the tables.

\section{RESULTS}

A total of 18 rats survived until the end of the study and were included in the final analyses. The animals in both groups were statistically similar in terms of weight gain, activity, appetite, and water intake. The mean adhesion severity and adhesion extent scores were $2.2 \pm 0.53$ and $0.61 \pm 0.25$ in the control group and $2.8 \pm 0.85$ and $0.92 \pm 0.26$ in the intervention group, respectively. The total adhesion scores were $2.81 \pm 0.75$ and $3.72 \pm 0.96$, respectively. All scores were significantly higher in the intervention group than in the control group ( $p<0.05$ for all; Table 1 ).

The evaluation of immunohistochemical parameters demonstrated that adhesion-related findings were

Table 1. Adhesion scores of the groups

\begin{tabular}{llll}
\hline & $\begin{array}{l}\text { Group 1 } \\
\text { (Control) }\end{array}$ & $\begin{array}{l}\text { Group 2 } \\
\text { (Absorbable } \\
\text { hemostat) }\end{array}$ & $\mathrm{p}$ \\
\hline Severity & $2.20 \pm 0.53^{\mathrm{a}}$ & $2.80 \pm 0.85^{\mathrm{b}}$ & $<0.05$ \\
\hline Extent & $0.61 \pm 0.25^{\mathrm{a}}$ & $0.92 \pm 0.26^{\mathrm{b}}$ & $<0.05$ \\
\hline Total score & $2.81 \pm 0.75^{\mathrm{a}}$ & $3.72 \pm 0.96^{\mathrm{b}}$ & $<0.05$ \\
\hline
\end{tabular}

Statistically significant difference is not present in groups sharing the same letter. Data are expressed as mean \pm standard deviation. All data sets of power of the performed test with alpha 0.050: 0.834-1.000. 
significantly increased in the absorbable hemostat recipients than the controls $(p<0.05$ for all; Table 2$)$.

Figure 1 shows the adhesion formation procedure and compares the macroscopic appearances of adhesion in both groups (1 month after the procedure). Cystic formation accompanied adhesion in absorbable hemostat recipients. Figure 2 shows the immunohistochemical screening of PMNL, MNL, vascular proliferation, and fibrosis. Figure 3 displays the Ki-67 scores of the groups.

\section{DISCUSSION}

The current study demonstrated that ORC-based absorbable hemostats (Surgicel@) may increase the severity and extent of adhesion formation after pelvic surgery. Macroscopic evaluations were consistent with the results obtained via immunohistochemistry and adhesion scores. Although the intraoperative and postoperative advantages of ORC-based hemostats cannot be questioned, the results
Table 2. Immunohistochemical scores of the adhesion areas in the groups

\begin{tabular}{llll}
\hline Parameters & $\begin{array}{l}\text { Group 1 } \\
\text { (control) }\end{array}$ & $\begin{array}{l}\text { Group 2 } \\
\text { (absorbable } \\
\text { hemostat) }\end{array}$ & p \\
\hline $\begin{array}{l}\text { PMNL index (acute } \\
\text { inflammation) }\end{array}$ & $2.15 \pm 0.51^{\mathrm{a}}$ & $2.32 \pm 0.61^{\mathrm{b}}$ & $<0.05$ \\
\hline $\begin{array}{l}\text { MNL index (chronic } \\
\text { inflammation) }\end{array}$ & $2.10 \pm 0.80^{\mathrm{a}}$ & $2.62 \pm 0.81^{\mathrm{b}}$ & $<0.05$ \\
\hline $\begin{array}{l}\text { Ki-67 index (proliferation } \\
\text { marker) }\end{array}$ & $2.07 \pm 0.42^{\mathrm{a}}$ & $2.25 \pm 0.66^{\mathrm{b}}$ & $<0.05$ \\
\hline $\begin{array}{l}\text { CD-31 index } \\
\text { (neovascularization } \\
\text { marker) }\end{array}$ & $1.92 \pm 0.5^{\mathrm{a}}$ & $2.32 \pm 0.45^{\mathrm{b}}$ & $<0.05$ \\
\hline $\begin{array}{l}\text { Masson Trichrome index } \\
\text { (fibrosis marker) }\end{array}$ & $2.02 \pm 0.54^{\mathrm{a}}$ & $2.25 \pm 0.56^{\mathrm{b}}$ & $<0.05$ \\
\hline
\end{tabular}

Statistically significant difference is not present in groups sharing the same letter. Note: Data is expressed as mean \pm SD. PML: Polymorphonuclear leucocytes MNL: Mononuclear leucocytes

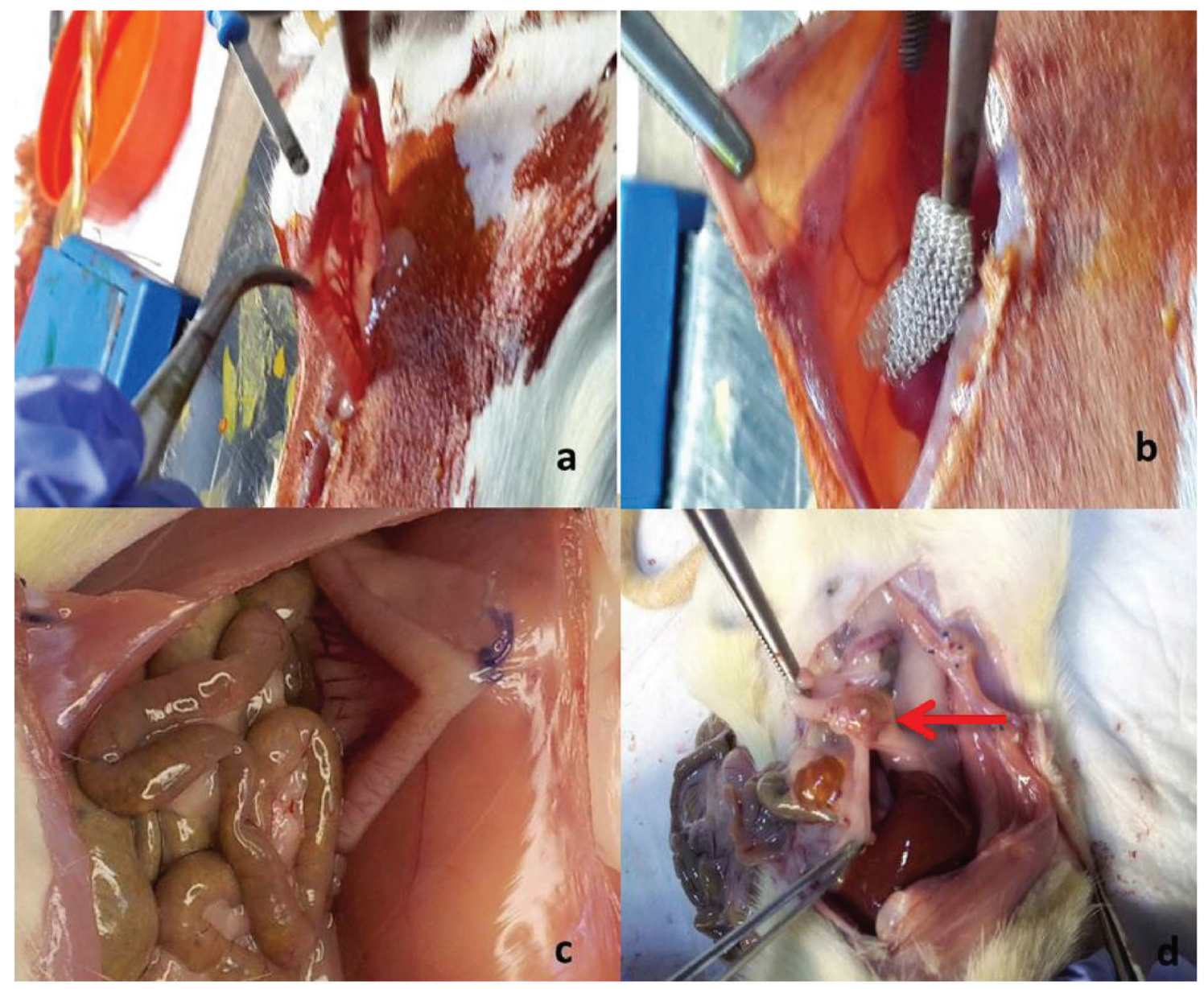

Figure 1. The macroscopic appearance of adhesion formation during and after 1 month. (a) and (c) Control group. (b) and (d) Absorbable hemostatic group and thickness showing cystic formations (a) Control group adhesion formation procedure and (b) absorbable hemostat group adhesion formation procedure. (c) Control group 1 month after surgery. (d) Absorbable hemostat group 1 month after surgery. Thickness showing cystic formation 


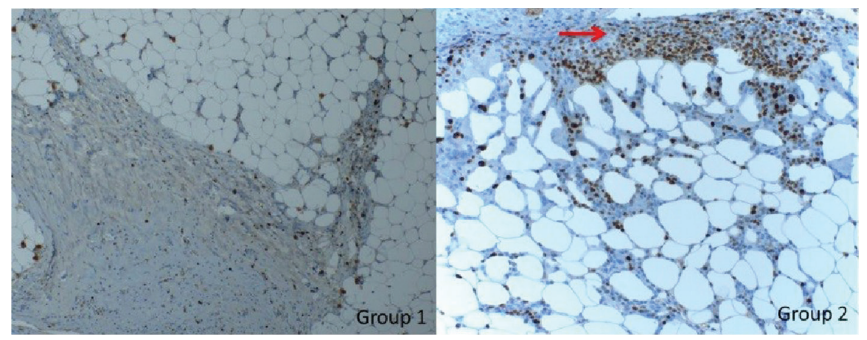

Figure 2. Immunohistochemical studies of the groups. Thickness showing aggregation of inflammatory cells

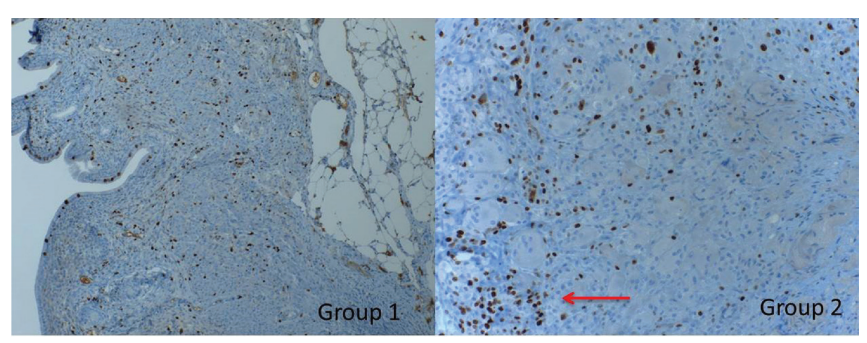

Figure 3. Ki-67 staining procedure for groups. Thickness showing proliferation of adhesion formation

of the present study indicated that these materials should be utilized sparingly, considering the risks imposed by their application.

As a consequence of pelvic inflammation, endometriosis, or direct trauma, pelvic adhesions may develop during operation. Reports utilizing second-look laparoscopy have shown that $25 \%$ to $92 \%$ of individuals may develop pelvic adhesion after laparoscopy $(21,22)$. Because of their ease of use, biocompatibility, bactericidal effects, and ultimate tissue absorption, ORC-based hemostatic materials have gained popularity in various fields of surgery (23). However, their utility in gynecology surgical practice has not been conclusively determined.

Numerous animal studies with different methodologies and results have been conducted to elucidate the effects of Surgicel $囚$ on adhesion development in experimental rat models. McGaw et al. (24) sacrificed all rats on the $7^{\text {th }}$ day after the operation and reported that Surgicel $($ use reduced abdominal adhesion formation, whereas Hoffman et al. (10) reported that both Surgicel® recipients and the control groups were similar in terms of adhesion scores. In a recent study, Güney et al. (11) investigated Surgicel and quercetin (again for 14 days) in relation to pelvic adhesion development in a rat model. In this study, all parameters examined in our study (adhesion score and subscores and immunohistochemistry for Ki-67, CD-31, MTC, PMNL, and $M N L)$ were significantly higher in the Surgicel ${ }^{\circledR}$ group than in the control group. Considering that ORC was completely resolved within $2-6$ weeks $(6,14,15)$, the most important reason we obtained different results from the majority of previous studies $(8,11,24,25)$ may be that we analyzed the effect of Surgicel ${ }^{\circledR}$ on pelvic adhesion formation on the $28^{\text {th }}$ postoperative day. Importantly, our findings suggest coherently that the use of Surgicel $₫$ may increase pelvic adhesion formation by causing local chronic pelvic inflammation.

Localized suppression of trauma-induced peritoneal fibrinolysis causes the development of early fibrinous adhesions, whereas an infestation of fibroblasts and blood vessels (that develop shortly after) may cause lasting adhesions with vascular features (26). Carboxyl groups on oxidized cellulose, which act as a matrix for solid fibrin clot development when added to the bleeding area, can lower the $\mathrm{pH}$ (27). Although low pH has theoretical advantages, such as potential antimicrobial and caustic action leading to potentiation of hemostasis and clotting, it also has disadvantages, such as the inactivation of biologically active coagulants, elevation of local inflammation, and prolongation of the normal healing process (28). Mesothelial cells respond to acidification by rising plasminogen activator inhibitor type-1 (PAI-1) (29). PAI-1 is the primary inhibitor of tissue plasminogen activator in the peritoneal cavity; therefore, its increase will downregulate fibrinolysis and could increase postoperative adhesion formation $(30,31)$. Furthermore, it has been shown that most of the cells seen in the $2^{\text {nd }}$ week of adhesion are fibroblasts, and in particular locations, macrophages and lymphocytes. An increased collagen volume is formed over a span of 2 weeks to 2 months, and the cellular adhesion material steadily becomes less concentrated, accompanied by small blood vessel formation (32). These physiological alterations cannot be accounted for within 2 weeks, suggesting that studies evaluating adhesion development should involve a longer follow-up period.

The most important limitation of our study may be the low number of rats used, and the other can be the method of lesion formation (via cautery). It is clearly understood that normal peritoneal mesothelium has fibrinolytic activity on the wound surface, gradually increasing from the $2^{\text {nd }}$ to the $8^{\text {th }}$ day (25). This effect of the peritoneal mesothelium, which may act reciprocally to the decrease in fibrinolytic activity caused by Surgicel $\AA^{\circledR}$, may be affected by cautery use. Therefore, our results may be in relation to this specific injury type; however, it is evident that such injuries may be frequently encountered in surgical practice.

This is the first study to examine the impacts of an ORCbased absorbable hemostat material (Surgicel@) on pelvic adhesion formation at the end of the postoperative $4^{\text {th }}$ week 
in a rat model. Our results, with an extensive set of analyses, including immunohistochemical staining methods and adhesion scoring, indicate that Surgicel $\circledast$ strongly increased adhesion scores, as well as the quantity and proportion of cells that tested positive for Ki-67, CD-31, and MTC, and the number of PMNL and MNL in specimens obtained from ORC-administered rats. These findings suggest that Surgicel $\circledast$ may have proliferative and inflammatory effects after the early period in which various studies have suggested protective effects against adhesion. In addition, the macroscopic evaluation showed cystic formation in the Surgicel® group. This finding supports that Surgicel®, although considered biocompatible, can trigger a foreign body reaction (15).

\section{Conclusion}

ORC-based hemostats can lead to increased severity and extent of adhesion, possibly caused by local pockets of chronic inflammation and foreign body reaction. However, further studies, which would benefit from utilizing other methods of lesion formation, are needed to ascertain the effects of ORC on adhesion development with regard to its clinical use.

Acknowledgment: We want to express our deepest thanks to Dr. Yalçın Polat for his efforts on pathological assessments.

\section{ETHICS}

Ethics Committee Approval: The study were approved by the Niğde Ömer Halisdemir University Animal Experimentation Local Ethics Committee (protocol number: 2020/09).

Informed Consent: Consent form was filled out by all participants.

\section{Authorship Contributions}

Surgical and Medical Practices: A.Y., S.Ç., Concept: A.Y., S.Ç., M.T., Design: A.Y., S.Ç., G.Ö., M.T., Data Collection or Processing: A.Y., S.Ç., G.Ö., Analysis or Interpretation: A.Y., G.Ö., Literature Search: A.Y., G.Ö., M.T., Writing: A.Y., G.Ö.

Conflict of Interest: No conflict of interest was declared by the authors.

Financial Disclosure: The authors declared that this study received no financial support.

\section{REFERENCES}

1. ten Broek RP, Issa $Y$, van Santbrink EJ, Bouvy ND, Kruitwagen RF, Jeekel J, et al. Burden of adhesions in abdominal and pelvic surgery: systematic review and met-analysis. BMJ 2013;347:5588.
2. Herrmann A, De Wilde RL. Adhesions are the major cause of complications in operative gynecology. Best Pract Res Clin Obstet Gynaecol 2016;35:71-83.

3. Achneck HE, Sileshi B, Jamiolkowski RM, Albala DM, Shapiro ML, Lawson JH. A comprehensive review of topical hemostatic agents: efficacy and recommendations for use. Ann Surg 2010;251:217-28.

4. Mudge MC. Chapter 4 - Hemostasis, Surgical Bleeding, and Transfusion. In: Auer JA, Stick JA, editors. Equine Surgery (Fourth Edition). Saint Louis: W.B. Saunders, 2012, 35-47.

5. Spangler D, Rothenburger S, Nguyen K, Jampani H, Weiss S, Bhende S. In vitro antimicrobial activity of oxidized regenerated cellulose against antibiotic-resistant microorganisms. Surg Infect (Larchmt) 2003;4:255-62.

6. Sileshi B, Achneck HE, Lawson JH. Management of surgical hemostasis: topical agents. Vascular. 2008;16 Suppl 1:S22-8.

7. Ito TE, Martin AL, Henderson EF, Gaskins JT, Vaughn VM, Biscette SM, et al. Systematic Review of Topical Hemostatic Agent Use in Minimally Invasive Gynecologic Surgery JSLS 2018;22:2018.00070.

8. Larsson B, Nisell H, Granberg I. Surgicel--an absorbable hemostatic material--in prevention of peritoneal adhesions in rats. Acta Chir Scand 1978;144:375-8.

9. Shimanuki T, Nishimura K, Montz FJ, Nakamura RM, diZerega GS. Localized prevention of postsurgical adhesion formation and reformation with oxidized regenerated cellulose. J Biomed Mater Res 1987;21:173-85.

10. Hoffmann NE, Siddiqui SA, Agarwal S, McKellar SH, Kurtz HJ, Gettman MT, et al. Choice of hemostatic agent influences adhesion formation in a rat cecal adhesion model. J Surg Res 2009;155:77-81.

11. Güney G, Kaya C, Oto G, Yıldırım S, Özdemir H, Tokmak A. Effects of quercetin and surgicel for preventing adhesions after gynecological surgery: A rat uterine horn model. J Obstet Gynaecol Res 2017;43:179-84.

12. Altun I. An Experimental Study of Histopathologic Effects of Hemostatic Agents Used in Spinal Surgery. World Neurosurg 2016;90:147-53.

13. Kaya C, Sever N, Cengiz H, Yıldız Ş, Ekin M, Yaşar L. A randomized controlled study of the efficacy of misoprostol and hyaluronic acid in preventing adhesion formation after gynecological surgery: a rat uterine horn model. Eur J Obstet Gynecol Reprod Biol 2014;176:449.

14. Barnard J, Millner R. A review of topical hemostatic agents for use in cardiac surgery. Ann Thorac Surg 2009;88:1377-83.

15. Tompeck AJ, Gajdhar AUR, Dowling M, Johnson SB, Barie PS, Winchell RJ, et al. A comprehensive review of topical hemostatic agents: The good, the bad, and the novel. J Trauma Acute Care Surg 2020;88:e1-21.

16. Linsky CB, Diamond MP, Cunningham T, Constantine B, DeCherney $\mathrm{AH}$, diZerega GS. Adhesion reduction in the rabbit uterine horn model using an absorbable barrier, TC-7. J Reprod Med 1987;32:1720.

17. Jean RA, O'Neill KM, Pei KY, Davis KA. Impact of hospital volume on outcomes for laparoscopic adhesiolysis for small bowel obstruction. J Surg Res 2017;214:23-31.

18. Sharma JB, Malhotra M. Topical oxidized cellulose for tubal hemorrhage hemostasis during laparoscopic sterilization. Int J Gynaecol Obstet 2003;82:221-2.

19. Kansra S, Yamagata S, Sneade L, Foster L, Ben-Jonathan N. Differential effects of estrogen receptor antagonists on pituitary lactotroph proliferation and prolactin release. Mol Cell Endocrinol 2005;239:27-36.

20. Sitruk-Ware R, Bricaire C, De Lignieres B, Yaneva H, Mauvais-Jarvis P. Oral micronized progesterone. Bioavailability pharmacokinetics, 
pharmacological and therapeutic implications--a review. Contraception 1987;36:373-402.

21. Ahmad G, Kim K, Thompson M, Agarwal P, O'Flynn H, Hindocha A, et al. Barrier agents for adhesion prevention after gynaecological surgery. Cochrane Database Syst Rev 2020;3:CD000475.

22. Okabayashi $K$, Ashrafian H, Zacharakis E, Hasegawa H, Kitagawa $Y$, Athanasiou $T$, et al. Adhesions after abdominal surgery: a systematic review of the incidence, distribution and severity. Surg Today 2014;44:405-20.

23. Franceschini G. Internal surgical use of biodegradable carbohydrate polymers. Warning for a conscious and proper use of oxidized regenerated cellulose. Carbohydr Polym 2019;216:213-6.

24. McGaw T, Elkins TE, DeLancey JO, McNeeley SG, Warren J Assessment of intraperitoneal adhesion formation in a rat model: can a procoagulant substance prevent adhesions? Obstet Gynecol 1988;71:774-8.

25. Raftery AT. Regeneration of peritoneum: a fibrinolytic study. J Anat 1979;129(Pt 3):659-64.
26. Penzias A, Bendikson K, Falcone T, Gitlin S, Gracia C, Hansen K et al. Postoperative adhesions in gynecologic surgery: a committee opinion. Fertility and sterility 2019:1;112:458-63.

27. Zhang S, Li J, Chen S, Zhang X, Ma J, He J. Oxidized cellulosebased hemostatic materials. Carbohydr Polym 2020;230:115585.

28. Pereira BM, Bortoto JB, Fraga GP. Topical hemostatic agents in surgery: review and prospects. Rev Col Bras Cir 2018;45:e1900.

29. Bergström M, Falk P, Holmdahl L. Effect of acidosis on expression of mesothelial cell plasminogen activator inhibitor type-1. Surg Endosc 2006;20:1448-52.

30. Falk K, Björquist $P$, Strömqvist $M$, Holmdahl L. Reduction of experimental adhesion formation by inhibition of plasminogen activator inhibitor type 1. Br J Surg 2001;88:286-9.

31. Holmdahl L, Eriksson E, Al-Jabreen M, Risberg B. Fibrinolysis in human peritoneum during operation. Surgery 1996;119:701-5.

32. Milligan DW, Raftery AT. Observations on the pathogenesis of peritoneal adhesions: a light and electron microscopical study. Br J Surg 1974;61:274-80 